\title{
EVALUATION OF SALICYLIC ACID IMPACT ON GROWTH AND YIELD OF ONION PLANTS UNDER SALINITY STRESS CONDITIONS
}

(Received: 25.11.2016)

\author{
By \\ A. H. M Abd Elwahed \\ Department of Horticulture, Faculty of Agriculture, Al-Azhar University, Cairo, Egypt.
}

\begin{abstract}
The present experiment was conducted at the Faculty of Agriculture, AL-Azhar University, Nasr City, Cairo, Egypt, during the two winter seasons of 2014-2015 and 2015-2016 to study the effect of three saline levels in diluted agricultural drainage water $(1000,2000$ and $3000 \mathrm{ppm})$ besides tap water as a control $(300 \mathrm{ppm})$ and three foliar salicylic acid (SA) concentrations $(0.0,1.0$ and $1.50 \mathrm{mM})$ at three times after 30, 45 and 60 days from transplanting and their interaction on the growth, yield and bulb quality of onion (Allium cepa L.) cultivar Giza 20. The obtained results showed that plant height, fresh weight, number of leaves, bulb fresh weight and diameter, leaf total chlorophyll, bulb dry weight and relative water contents were significantly decreased with increasing the saline water levels from $1000 \mathrm{ppm}$ up to $3000 \mathrm{ppm}$. On contrast, leaf proline content and bulb contents of T.S.S, ascorbic acid significantly increased with increasing the saline water levels up to $3000 \mathrm{ppm}$ if compared with the control $(300 \mathrm{ppm})$. On the other hand, data indicated that all the tested parameters were significantly increased as a result the spray by SA at $1.0 \mathrm{mM}$ compared with $1.5 \mathrm{mM}$ concentration in the untreated plants. The interaction of between treatments indicated that the application of SA at $1.0 \mathrm{mM}$ was the most effective in increasing the above mentioned characteristics under the different saline and the control level. In this respect, it could be concluded that spraying onion plants with SA at the concentration of $1.0 \mathrm{mM}$ could reduce the adverse effects of saline irrigation water on growth and the yield.
\end{abstract}

Key words: salinity, salicylic acid, growth, onion.

\section{INTRODUCTION}

Onion (Allium cepa L.) is one of the most important vegetable crops for local consumption and exportation, which ranked third after potato and tomatoes in Egypt. Onion is classified as a salinity sensitive crop (Change and Randle, 2004). Salt stress proves to be a strong inhibitor of plant growth and development. High levels of salt stress are found to produce ion imbalance and osmotic stress in different crops (Maggio et al., 2000). These harmful effects cause an oxidative damage that may end up in decreasing the growth of the plants (Zhu, 2001). Various methods are being exercised to ameliorate the adverse effects of salinity such as exogenous foliar applications of compatible solutes as well as salicylic acid. Salicylic acid (SA) is an endogenous plant growth regulator which participates in regulating a wide range of metabolic and physiological processes in plants thereby affecting their growth and development (Raskin, 1992). SA plays an important role in abiotic stress tolerance, and more interests have focused on SA due to its ability to induce a protective effect on plants under salinity stress (Stevens et al., 2006). Therefore, the objective of present study was to evaluate the effect of different concentrations of SA applied as foliar spray on the growth and the changes in the physical and chemical characteristics of onion plants grown under salinity stress.

\section{MATERIALS AND METHODS}

This experiment was carried out at the farm of the Faculty of Agriculture, Al-Azhar University, Nasr city, Cairo, Egypt, during the two winter seasons of 2014-2015 and 2015-2016 to study the effect of the different concentrations of irrigation with saline agriculture drainage water, salicylic acid (SA) and their combination on growth and yield of onion (Allium cepa $\mathrm{L}$.) Giza 20 cultivar. The used drainage water was brought from Karoun Lake at El- Fayoum Governorate where the salt concentration 28000 
ppm. This saline water was diluted to the required three salt concentrations of 1000, 2000 and $3000 \mathrm{ppm}$ while the control plants was irrigated with tap water at the concentration of $300 \mathrm{ppm}$. The chemical analyses of the used diluted drainage water are shown in Table (1). Five onion seedlings are transplanted on December the $15^{s t}$ in the two seasons in plastic pots of $40 \mathrm{~cm}$ diameter, containing $18 \mathrm{~kg}$ of dried sandy clay loam soil. The physical and chemical analyses of the used soil are exhibited in Table (2). Irrigation with saline water was initiated after 20 days from transplanting. Plants were sprayed with different concentrations of SA $(0.0,1.0,1.5 \mathrm{mM})$ at 30,45 and 60 days from transplanting. The pots were arranged in a randomized complete block design in factorial arrangement with three replications. Each replicate had 12 treatments. Each treatment consisted of three pots. All the plants received the recommended doses of soil fertilizers according to Hassan (1988) as follow; $5.4 \mathrm{~g}$ of number of leaves per plant. Leaf chemical analysis for total chlorophyll was determined according to Lichtenthaler (1987). Total proline content was determined according to Bates et al., (1973). At harvest after 140 days from transplanting, nine bulbs were chosen randomly from each treatment and the following physical characteristics were recorded; bulb weight and diameter. Chemical constituents for ascorbic acid and total soluble solids in bulb were determined according to A.O.A.C. (1990). Dry weight was determined by drying $100 \mathrm{~g}$. bulb fresh weight in an oven at $70{ }^{\circ} \mathrm{c}$ until constant weight was reached. In addition, water relations as relative water content was calculated according to Korkmaz et al, (2010).

Data were subjected to statistical analysis using the analysis of variance methods and the means of treatments were compared by using the Least Significant Different (L.S.D) at 5\% level of probability according to Snedecor and Cochran (1980).

Table (1): The chemical analyses of the used saline drainage water ( $\mathrm{meq} / \mathrm{l}$.).

\begin{tabular}{|c|c|c|c|c|c|c|c|c|}
\hline Concentrations & $\mathbf{C o}_{3}^{--}$ & $\mathbf{H C O}_{3}^{-}$ & $\mathbf{C l}^{-}$ & $\mathbf{S O}_{4}^{-}$ & $\mathbf{C a}^{++}$ & $\mathbf{M g}^{++}$ & $\mathbf{N a}^{+}$ & $\mathbf{K}^{+}$ \\
\hline $300 \mathrm{ppm}$ & - & 2.8 & 1.3 & 0.1 & 1.6 & 1.3 & 1.1 & 0.2 \\
$1000 \mathrm{ppm}$ & - & 2.8 & 9.6 & 0.2 & 2.1 & 3.1 & 7.1 & 0.3 \\
$2000 \mathrm{ppm}$ & - & 2.8 & 21.5 & 0.5 & 2.5 & 5.9 & 15.9 & 0.5 \\
$3000 \mathrm{ppm}$ & - & 2.8 & 32.1 & 0.8 & 3.1 & 9.3 & 22.6 & 0.7 \\
\hline
\end{tabular}

Table (2): The physical and chemical properties of pot soil.

\begin{tabular}{|c|c|c|c|c|c|c|c|c|c|c|c|c|}
\hline \multicolumn{4}{|c|}{ Physical properties } & \multicolumn{9}{|c|}{ Chemical properties } \\
\hline Clay & Silt & Sand & Texture & \multicolumn{5}{|c|}{ Cation meq/l } & \multicolumn{4}{|c|}{ Anion meq/l } \\
\hline \multirow{2}{*}{$\begin{array}{l}23.2 \\
5\end{array}$} & \multirow{2}{*}{$\begin{array}{l}10.7 \\
0\end{array}$} & \multirow{2}{*}{$\begin{array}{l}66.0 \\
6\end{array}$} & \multirow{2}{*}{$\begin{array}{l}\text { Sand clay } \\
\text { loam }\end{array}$} & $\mathrm{pH}$ & $\mathrm{Ca}^{++}$ & $\mathrm{Mg}^{+}$ & $\mathrm{Na}^{+}$ & $\mathrm{K}^{+}$ & $\mathrm{Co}$ & $\mathrm{HcO}_{3}^{-}$ & $\mathrm{Cl}^{-}$ & $\mathrm{So}_{4}$ \\
\hline & & & & 7.61 & 0.56 & 0.38 & 0.88 & 0.17 & 0 & 0.51 & 1.02 & 0.46 \\
\hline
\end{tabular}

super calcium phosphate was applied at soil preparation, $1.8 \mathrm{~g}$ of Potassium sulphate divided into two doses, where the first dose was added during preparing the soil for plantation, and the second dose was applied after 60 days from transplanting and $7.2 \mathrm{~g}$ ammonium sulfate was added in two equal doses at 60 and 90 days from transplanting. After 115 days from transplanting, plant physical characteristics were recorded expressed as plant height, fresh weight and

\subsection{Plant characteristics \\ 3.1.1. Physical characteristics}

The effect of irrigation with the different saline water levels, salicylic acid concentrations and their interaction on the plant physical characteristics of onion plants Table (3) indicate significant decrease in the values of plant height, fresh weight and number of leaves per plant 
Table (3): Effect of different saline water levels, salicylic acid (SA) concentrations and their interactions on the plant physical characteristics and chemical constituents of onion during the two seasons of 2014-2015 and 20152016.

\begin{tabular}{|c|c|c|c|c|c|c|c|c|c|c|c|}
\hline \multirow{3}{*}{$\begin{array}{l}\text { Saline levels } \\
\quad \text { (ppm) }\end{array}$} & \multirow{3}{*}{$\begin{array}{l}\text { SA Concs. } \\
(\mathrm{mM})\end{array}$} & \multicolumn{6}{|c|}{ Plant physical characteristics } & \multicolumn{4}{|c|}{ Plant chemical constituents } \\
\hline & & \multicolumn{2}{|c|}{ Plant height (cm) } & \multicolumn{2}{|c|}{$\begin{array}{c}\text { Plant fresh weight } \\
\text { (g) }\end{array}$} & \multicolumn{2}{|c|}{ Number of leaves } & \multicolumn{2}{|c|}{$\begin{array}{c}\text { Total chlorophyll } \\
\text { (mg/g. f.w.) }\end{array}$} & \multicolumn{2}{|c|}{ Proline (mg/g. f.w.) } \\
\hline & & $\begin{array}{l}\text { 2014-2015 } \\
\text { season }\end{array}$ & $\begin{array}{l}\text { 2015-2016 } \\
\text { season }\end{array}$ & $\begin{array}{l}\text { 2014-2015 } \\
\text { season }\end{array}$ & $\begin{array}{l}2015-2016 \\
\text { season }\end{array}$ & $\begin{array}{l}\text { 2014-2015 } \\
\text { season }\end{array}$ & $\begin{array}{l}\text { 2015-2016 } \\
\text { season }\end{array}$ & $\begin{array}{l}\text { 2014-2015 } \\
\text { season }\end{array}$ & $\begin{array}{l}\text { 2015-2016 } \\
\text { season }\end{array}$ & $\begin{array}{l}\text { 2014-2015 } \\
\text { season }\end{array}$ & $\begin{array}{l}\text { 2015-2016 } \\
\text { season }\end{array}$ \\
\hline \multirow{3}{*}{$\begin{array}{l}\text { Control } \\
(300)\end{array}$} & $\mathbf{0 . 0}$ & 60.00 & 58.76 & 89.25 & 81.73 & 8.69 & 9.70 & 6.80 & 6.77 & 15.87 & 16.52 \\
\hline & 1.00 & 61.16 & 60.88 & 89.91 & 83.43 & 9.40 & 10.16 & 6.95 & 7.19 & 16.08 & 16.96 \\
\hline & 1.5 & 58.43 & 56.20 & 87.63 & 81.27 & 8.54 & 9.43 & 6.58 & 6.23 & 14.90 & 16.14 \\
\hline \multicolumn{2}{|l|}{ Mean } & 60.19 & 58.70 & 88.93 & 82.14 & 8.87 & 9.76 & 6.77 & 6.73 & 15.61 & 16.54 \\
\hline \multirow[t]{3}{*}{1000} & $\mathbf{0 . 0}$ & 56.13 & 54.3 & 85.61 & 77.76 & 8.38 & 9.16 & 6.78 & 6.34 & 23.65 & 23.71 \\
\hline & 1.00 & 60.46 & 59.90 & 89.42 & 82.34 & 8.96 & 9.73 & 6.89 & 7.09 & 24.02 & 24.16 \\
\hline & 1.5 & 55.58 & 52.10 & 82.56 & 74.43 & 8.40 & 8.83 & 6.23 & 5.88 & 22.99 & 23.21 \\
\hline \multicolumn{2}{|l|}{ Mean } & 57.39 & 55.43 & 85.86 & 78.17 & 8.58 & 9.24 & 6.63 & 6.44 & 23.54 & 23.69 \\
\hline \multirow[t]{3}{*}{2000} & 0.0 & 50.23 & 46.76 & 76.57 & 70.41 & 6.00 & 6.23 & 5.65 & 5.74 & 34.69 & 35.88 \\
\hline & 1.00 & 53.30 & 49.90 & 80.86 & 75.32 & 6.50 & 6.76 & 5.97 & 6.58 & 35.06 & 36.11 \\
\hline & 1.5 & 47.13 & 45.00 & 70.43 & 69.76 & 5.30 & 5.86 & 5.47 & 5.51 & 34.12 & 35.45 \\
\hline \multicolumn{2}{|l|}{ Mean } & 50.22 & 47.22 & 75.95 & 71.83 & 5.93 & 6.28 & 5.69 & 5.83 & 34.62 & 35.81 \\
\hline \multirow[t]{3}{*}{3000} & 0.0 & 42,10 & 38.16 & 58.70 & 54.95 & 5.46 & 6.20 & 4.58 & 5.20 & 37.15 & 38.48 \\
\hline & 1.00 & 44.83 & 41.48 & 61.20 & 58.22 & 5.88 & 6.36 & 5.41 & 5.87 & 38.08 & 38.89 \\
\hline & 1.5 & 39.32 & 36.18 & 56.46 & 53.15 & 4.45 & 5.16 & 4.33 & 4.64 & 36.68 & 38.20 \\
\hline \multicolumn{2}{|c|}{ Mean } & 42.08 & 38.61 & 58.78 & 55.44 & 5.26 & 5.91 & 4.77 & 5.24 & 37.31 & 38.52 \\
\hline \multirow{3}{*}{\multicolumn{2}{|c|}{ Mean of SA Concs. }} & 52.40 & 51.73 & 77.53 & 71.21 & 7.13 & 7.82 & 5.95 & 6.01 & 27.84 & 28.65 \\
\hline & & 55.14 & 53.04 & 80.34 & 74.82 & 7.68 & 8.25 & 6.29 & 6.68 & 28.31 & 29.03 \\
\hline & & 50.11 & 47.37 & 74.27 & 69.65 & 6.67 & 7.32 & 5.65 & 5.47 & 27.15 & 28.25 \\
\hline \multirow[t]{3}{*}{ L.S.D at 5\% } & Saline levels (SL) & 2.27 & 1.43 & 2.11 & 2.82 & 0.76 & 0.60 & 0.16 & 0.07 & 0.10 & 0.06 \\
\hline & SA Concs. & 1.79 & 1.12 & 1.82 & 2.44 & 0.46 & 0.50 & 0.15 & 0.06 & 0.09 & 0.05 \\
\hline & SL X SA & 0.82 & 0.60 & 0.70 & 0.99 & 0.94 & 0.64 & 0.25 & 0.21 & 0.08 & 0.05 \\
\hline
\end{tabular}


with increasing the saline water levels from 1000 to $3000 \mathrm{ppm}$ compared with the control. Concerning the effect of salicylic acid, data showed that plant height, fresh weight and the number of leaves were significantly increased as a result of foliar SA application at the concentration of $1.0 \mathrm{mM}$ compared with the higher concentration of SA $(1.5 \mathrm{mM})$. The interaction between the treatments reflected that foliar SA application at the concentration of 1.0 $\mathrm{mM}$ recorded the best results in increasing the above mentioned characteristics for the plants subjected to the irrigation with the different saline levels especially the level of $1000 \mathrm{ppm}$ and the control level of $300 \mathrm{ppm}$.

\subsubsection{Chemical constituents}

Data presented in Table (3) showed that the total chlorophyll and proline contents in the leaves were significantly affected with irrigation by the different saline water levels, foliar spray with the different concentrations of SA and their interaction. Concerning the total chlorophyll content, the figures reflected that the increase in the saline levels up to $3000 \mathrm{ppm}$ significantly decreased this content in the leaves of onion plants. On the other hand, the data cleared that total chlorophyll content was significantly increased using the low concentration of SA at $1.0 \mathrm{mM}$ compared with the high dose of SA at $1.5 \mathrm{mM}$ and untreated plants. In other words, the concentration of SA at $1.0 \mathrm{mM}$ proved to be the most effective in increasing the leaf total chlorophylls content under the different saline levels and the control level of $300 \mathrm{ppm}$.

The same table showed that the content of proline in the leaves significantly increased with every increase in the water saline levels. At the same time, data indicated that spray with concentration of SA at $1.0 \mathrm{mM}$ had a significant increase in the accumulation of proline, while more than this concentration significantly decreased this content. The interaction between saline water levels and salicylic acid concentrations reflected that the highest significant value of proline content happened in the saline water level at $3000 \mathrm{ppm}$ and the treated plants with $1.0 \mathrm{mM} \mathrm{SA}$, while the lowest value appeared in the plants subjected to the control level of $300 \mathrm{ppm}$ and unsprayed with SA.

\subsection{Bulb characteristics}

\subsubsection{Physical characteristics}

Data reported in Table (4) indicated that the application of the different saline water levels, concentrations of salicylic acid and their interaction had significant effects on the tested bulb physical characteristics. The bulb fresh weight and diameter significantly decreased with increasing water saline levels up to $3000 \mathrm{ppm}$ compared with the control level. Evidences from salicylic acid concentrations recorded that the concentration of $1.0 \mathrm{mM}$ was much better in increasing the bulb weight and diameter than the concentration of $1.5 \mathrm{mM}$ and the untreated plants. Hence, the plants irrigated by the saline level of $1000 \mathrm{ppm}$ or the control level of 300 ppm and sprayed with the concentration of 1.0 $\mathrm{mM}$ SA produced the highest values in bulb physical characteristics and the opposite was true from using the saline level of $3000 \mathrm{ppm}$ and the foliar SA at $1.5 \mathrm{mM}$.

\subsubsection{Chemical constituents}

The data concerning the effect of the different saline water levels, concentrations of salicylic acid and their interaction on the bulb T.S.S and ascorbic acid contents (Table 4) reflected that irrigation with all the saline water levels induced significant increases in T.S.S and ascorbic acid contents in proportion to the control level. With respect to the effect of salicylic acid concentrations, it was found that the contents of T.S.S and ascorbic acid in the bulbs significantly increased by using SA concentration of $1.0 \mathrm{mM}$ as compared with the concentration of $1.5 \mathrm{mM}$ and the unsprayed plants. The interaction effect between saline water levels and salicylic acid concentrations showed that the highest significant values of T.S.S and ascorbic acid contents recorded from using the saline level of $3000 \mathrm{ppm}$ and the concentration of $1.0 \mathrm{mM} \mathrm{SA}$, while the lowest one resulted from the control level of $300 \mathrm{ppm}$ and the concentration of 1.5 mM SA.

Data pertaining to the effect of irrigation with the different saline water levels, foliar spray with the different concentrations of salicylic acid and their interaction on the bulb dry weight content (Table 4) cleared that the dry weight content significantly decreased by the increase of the saline water levels till $3000 \mathrm{ppm}$ compared with the control level. The data of the foliar application of salicylic acid exhibited that the dry weight content significantly increased with the application of SA at $1.0 \mathrm{mM}$, then turned to a significant decrease correlated with the high concentration of $1.5 \mathrm{mM}$. Thus, the greatest accumulation of dry weight content in the bulb exerted from the saline water level of $1000 \mathrm{ppm}$ or the control level of $300 \mathrm{ppm}$ and the concentration of $1.0 \mathrm{mM} \mathrm{SA}$, whereas the least 
Table (4): Effect of different saline water levels, salicylic acid (SA) concentrations and their interactions on the bulb physical characteristics and chemical constituents and relative water content of onion during the two seasons of 2014-2015 and 20152016.

\begin{tabular}{|c|c|c|c|c|c|c|c|c|c|c|c|c|c|}
\hline \multirow{3}{*}{$\begin{array}{l}\text { Saline levels } \\
\text { (ppm) }\end{array}$} & \multirow{3}{*}{$\begin{array}{l}\text { SA Concs. } \\
(\mathrm{mM})\end{array}$} & \multicolumn{4}{|c|}{ Bulb physical characteristics } & \multicolumn{6}{|c|}{ Bulb chemical constituents } & \multirow{2}{*}{\multicolumn{2}{|c|}{$\begin{array}{c}\text { Relative water } \\
\text { content }(\%)\end{array}$}} \\
\hline & & \multicolumn{2}{|c|}{$\begin{array}{c}\text { Bulb fresh weight } \\
\text { (g) }\end{array}$} & \multicolumn{2}{|c|}{$\begin{array}{c}\text { Bulb diameter } \\
(\mathbf{c m})\end{array}$} & \multicolumn{2}{|c|}{$\begin{array}{l}\text { Dry weight } \\
\text { (g/100 g f.w) }\end{array}$} & \multicolumn{2}{|c|}{$\begin{array}{l}\text { Ascorbic acid } \\
\text { (mg/100 g f.w) }\end{array}$} & \multicolumn{2}{|c|}{ T.S.S \% } & & \\
\hline & & $\begin{array}{l}2014- \\
2015 \\
\text { season }\end{array}$ & $\begin{array}{l}2015- \\
2016 \\
\text { season } \\
\end{array}$ & $\begin{array}{l}2014- \\
2015 \\
\text { season }\end{array}$ & $\begin{array}{l}2015- \\
2016 \\
\text { season }\end{array}$ & $\begin{array}{l}2014- \\
2015 \\
\text { season }\end{array}$ & $\begin{array}{l}2015- \\
2016 \\
\text { season } \\
\end{array}$ & $\begin{array}{l}2014- \\
2015 \\
\text { season }\end{array}$ & $\begin{array}{l}2015- \\
2016 \\
\text { season }\end{array}$ & $\begin{array}{l}2014- \\
2015 \\
\text { season }\end{array}$ & $\begin{array}{l}2015- \\
2016 \\
\text { season } \\
\end{array}$ & $\begin{array}{l}2014- \\
2015 \\
\text { season }\end{array}$ & $\begin{array}{l}2015- \\
2016 \\
\text { season } \\
\end{array}$ \\
\hline \multirow{3}{*}{$\begin{array}{l}\text { Control } \\
\text { (30o) }\end{array}$} & $\mathbf{0 . 0}$ & 40.83 & 40.87 & 4.26 & 4.30 & 15.36 & 14.67 & 11.10 & 11.66 & 11.46 & 11.10 & 84.33 & 87.12 \\
\hline & 1.00 & 42.40 & 43.63 & 4.56 & 4.70 & 16.12 & 15.86 & 11.88 & 12.00 & 11.86 & 11.88 & 87.80 & 90.01 \\
\hline & 1.5 & 39.20 & 38.80 & 3.91 & 3.82 & 14.73 & 14.45 & 10.50 & 10.98 & 11.13 & 10.51 & 83.45 & 84.22 \\
\hline \multirow[t]{3}{*}{1000} & $\mathbf{0 . 0}$ & 38.03 & 37.33 & 4.01 & 4.06 & 15.20 & 14.29 & 12.85 & 13.11 & 12.43 & 12.85 & 82.71 & 83.72 \\
\hline & 1.00 & 41.56 & 42.60 & 4.26 & 4.30 & 16.00 & 15.64 & 13.11 & 13.76 & 12.63 & 13.11 & 85.72 & 86.96 \\
\hline & 1.5 & 35.37 & 36.86 & 3.70 & 3.64 & 14.06 & 12.82 & 11.91 & 12.83 & 12.26 & 11.91 & 80.12 & 80.64 \\
\hline \multicolumn{2}{|l|}{ Mean } & 38.10 & 38.93 & 4.05 & 4.00 & 15.08 & 14.25 & 12.62 & 13.23 & 12.44 & 12.62 & 82.85 & 83.77 \\
\hline \multirow[t]{3}{*}{2000} & 0.0 & 28.80 & 27.93 & 3.53 & 3.36 & 13.99 & 12.60 & 13.23 & 14.40 & 13.20 & 13.91 & 78.60 & 79.66 \\
\hline & 1.00 & 32.85 & 31.50 & 4.03 & 4.13 & 14.50 & 13.00 & 14.18 & 14.80 & 13.50 & 14.18 & 80.86 & 82.36 \\
\hline & 1.5 & 24.93 & 23.30 & 3.32 & 3.04 & 13.23 & 11.09 & 13.91 & 14.01 & 12.96 & 13.23 & 75.15 & 77.66 \\
\hline \multirow[t]{3}{*}{3000} & 0.0 & 18.90 & 18.50 & 2.90 & 3.00 & 10.45 & 10.22 & 15.18 & 15.71 & 13.93 & 15.18 & 73.61 & 74.20 \\
\hline & 1.00 & 22.13 & 20.70 & 3.03 & 3.26 & 11.17 & 10.92 & 15.56 & 15.95 & 14.13 & 15.56 & 75.41 & 78.11 \\
\hline & 1.5 & 16.80 & 16.33 & 2.15 & 2.61 & 9.17 & 9.00 & 14.88 & 15.40 & 13.80 & 14.88 & 71.05 & 73.80 \\
\hline \multicolumn{2}{|l|}{ Mean } & 19.30 & 18.51 & 2.69 & 2.95 & 10.26 & 10.04 & 15.21 & 15.68 & 13.95 & 15.21 & 73.35 & 75.37 \\
\hline \multirow{3}{*}{\multicolumn{2}{|c|}{ Mean of SA Concs. }} & 31.23 & 31.15 & 3.71 & 3.71 & 13.75 & 12.94 & 13.26 & 13.72 & 12.75 & 13.26 & 79.81 & 81.17 \\
\hline & & 34.73 & 34.60 & 3.97 & 4.99 & 14.44 & 13.85 & 13.68 & 14.13 & 13.03 & 13.68 & 82.44 & 84.36 \\
\hline & & 29.48 & 28.57 & 3.27 & 3.27 & 12.79 & 11.84 & 12.63 & 13.30 & 12.54 & 12.62 & 77.44 & 79.08 \\
\hline \multirow[t]{3}{*}{ L.S.D at $5 \%$} & Saline levels (SL) & 1.64 & 2.44 & 0.21 & 0.23 & 0.21 & 0.20 & 0.23 & 0.14 & 0.08 & 0.23 & 0.92 & 0.84 \\
\hline & SA Concs. & 1.42 & 2.11 & 0.18 & 0.20 & 0.16 & 0.11 & 0.21 & 0.12 & 0.07 & 0.21 & 0.74 & 0.70 \\
\hline & SL X SA & 0.85 & 1.33 & 0.49 & 0.77 & 0.43 & 0.38 & 0.22 & 0.13 & 0.08 & 0.22 & 1.23 & 1.01 \\
\hline
\end{tabular}


one resulted from the level of $3000 \mathrm{ppm}$ and the foliar SA at $1.5 \mathrm{mM}$.

\subsection{Water relation}

\subsubsection{Water relative content}

The listed data in Table (4) reflected the changes occurred in the leaf relative water content as affected by the different saline water levels, concentrations of SA and their interaction. A significant decrease in relative water content resulted from the irrigation with the saline levels from $1000 \mathrm{ppm}$ till $3000 \mathrm{ppm}$ compared with the control level. On the other side, the sprayed plants with the concentration of $1.0 \mathrm{mM} \mathrm{SA}$ induced the highest significant increase over the other concentrations. The best significant value of relative water content resulted from the spray by the concentration of $1.0 \mathrm{mM}$ SA besides the saline water level of $1000 \mathrm{ppm}$ and the control level of $300 \mathrm{ppm}$, while the least one was obtained from the saline level of $3000 \mathrm{ppm}$ and the application of $1.5 \mathrm{mM}$ SA.

\section{DISCUSSION}

The objective of the present work was to study the effect of irrigation with different levels of saline water on onion plants and to answer the question if the foliar spray with the different concentrations of salicylic acid (SA) can be effective in mitigating the adverse effects of salt stress on growth and yield of onion?. The results showed that there were significant decline of the plant height, fresh weight and the number of leaves besides bulb fresh weight and diameter with increasing saline water levels from 1000 ppm up to $3000 \mathrm{ppm}$ as compared with the control level of $300 \mathrm{ppm}$. The inhibitory effects of salinity on growth of onion plants may be due to decreased water absorption, disturbed metabolic processes leading to reduction in meristematic activity and cell enlargement (Kaydan and Okut, 2007), coupled with an increase in respiration rate resulting from high energy requirements. There are two ways that salinity stress could retard growth, either by damaging cell growth so that they cannot perform their functions or by limiting their supply of essential metabolites (Hussein et al., 2012). Furthermore, increased salt content in irrigation water may cause directly ionic toxicity resulting from the accumulation of specific ion such as $\mathrm{Na}$ and $\mathrm{Cl}$ in the cytoplasm which inhibits the production of chlorophyll in leaves (Al-Safadi and Faoury, 2004). In addition to reduction in light utilization efficiency due to partial stomatal closure and simultaneously decreased $\mathrm{Co}_{2}$ fixation which in turn induced decreasing plant photosynthesis (Schwarz et al., 2002) and reduction in the vegetative growth and bulb fresh weight and diameter (Al-Zohiri, 2009).

Concerning the changes in the chemical characteristics, it is obvious that the leaf total chlorophyll content decreased with increasing saline water levels up to $3000 \mathrm{ppm}$. This result may be related to enhance activity of the chlorophyll-degrading enzyme, chlorophyllase, as suggested by researchers that increasing saline increased oxidation of chlorophyll leading to its decreased concentration (Jaleel et al., 2008). In the current study, the proline content in the leaf significantly increased with every increase in the water saline levels. This result supports the hypothesis that proline accumulation is a part of physiological response of the plant to intense salinity stress which led to decrease the osmotic potential. Therefore, the accumulation of proline may be through an increase in its synthesis constantly with inhibition of its catabolism (Jaleel et al., 2007).

Regarding the increase in ascorbic acid content as a result for increasing the saline water levels up to $3000 \mathrm{ppm}$ comparing with the control level of $300 \mathrm{ppm}$, this feature may be linked to the key role of ascorbic acid as a strong antioxidant for protecting the plant from the detrimental effects of salinity (Ali and Ismail, 2014). At the same time, the increase in the content of total soluble solids in the onion bulbs due to the increase in the saline water levels up to $3000 \mathrm{ppm}$ may be attributed to the fact the plant push to regulate certain metabolic activity under the salinity stress by degradation of polysaccharides to simple sugars thereby arise in T.S.S which play an important role in osmotic adjustment in plant (Benbella, 1999). In this regard, osmotic adjustment is a mechanism to maintain water relations under osmotic stress. On the other hand, the decrease of dry weight content of bulb correlated with increasing the saline water levels up to $3000 \mathrm{ppm}$ may be due to the decrease in chlorophyll formation and relative water content in the leaf leading to a reduction in photosynthesis and accumulation of dry weight content (Schwarz et al., 2002).

The decrease of relative water content in leaf as a result to the increase in the saline water levels till 3000 ppm may be explained that the leaf relative water content is considered as a valuable parameter to determine plants water 
status (Flower and Ludlow, 1986). Hence, reduced relative water content could be a result of lower water availability under saline conditions (Shalhevet, 1993). It may be also a consequence of inefficient root system which could not retrieve the water losses because of decreasing its absorbing surface (Gadallah, 2000).

The obtained results reflected that foliar spray with salicylic acid at the concentration of $1.0 \mathrm{mM}$ the best results in increasing the physical characteristics of the plant and bulb such as plant height, fresh weight and the number of leaves and bulb weight and diameter for plants subjected to the irrigation with the different saline levels especially the level of $1000 \mathrm{ppm}$ and control level of $300 \mathrm{ppm}$. Salicylic acid could act as an endogenous regulator in plants and induces plant tolerance against salinity stress (Horváth et al., 2007). SA plays an important role in the regulation of some physiological processes in plants such as its effects on plant growth and productivity (Simaei et al., 2012). This may be related to SA alleviating the adverse effect of salinity by increasing growth hormones such as IAA and cytokinins, reducing the uptake and accumulation of toxic ions and maintaining the cellular membrane integrity which leads to improve cell division and plant growth (Borsani et al. (2001). In addition, it increases $\mathrm{CO}_{2}$ assimilation and photosynthetic rate and increase mineral uptake in stressed plant (Szepesi et al., 2005). Th enhancing the vegetative growth traits as a result of spraying salicylic acid at $1.0 \mathrm{mM}$ (Table 3), which, in turn reflects this increase in bulb parameters.

Concerning the changes in the chemical contents of the onion plant, the data pertaining to interaction effect of saline water levels and SA concentrations clearly indicated that the concentration of $1.0 \mathrm{mM} \mathrm{SA}$ was found to be more efficient in mitigating the salinity stress by increasing chlorophyll in the leaf. This result may be related to the benefit effect of salicylic acid in promoting protective reactions to the photosynthetic pigments (El Tayeb, 2005). Here, it is worthy to note that the efficiency of exogenous SA depends on multiple causes such as the species, developmental stage, application method and SA concentration (Borsani et al., 2001). The present study showed that there was a significant increase in proline content in the leaf as a result of the increase of saline water levels up to $3000 \mathrm{ppm}$ and the concentration of salicylic acid at $1.0 \mathrm{mM}$. This result might suggest that application of salicylic acid contributes to the accumulation of this amino acid under salinity stress through a reduction in dissolved proteins (El-Tayeb, 2005). Furthermore, accumulation of proline reduces osmotic potential in the cytoplasm and contributes to maintaining water homeostasis among several cellular compartments (Sairan and Tyagi, 2004). Thus, proline is considered one of the important factors involved in SA induced protective mechanism in onion leaves in response to salinity stress.

The foliar SA at the concentration of $1.0 \mathrm{mM}$ was the most effective leading to increase ascorbic acid content in bulb for plants subjected to the irrigation with the different saline levels. This result confirmed the important function of SA in the tolerance to salinity stress because application of SA led to stimulate the activity antioxidant enzymes which protect the plants from the oxidative damage (Azooz et al., 2011). Also, the increase in T.S.S content in the bulb resulting from the foliar spray with the SA concentration of $1.0 \mathrm{mM}$ for plants irrigated with the different saline levels may be attributed to the role of salicylic acid to improve membrane permeability which facilitate absorption and utilization of mineral nutrients and transport of assimilates under stress conditions (Javaheri, et al., 2012 and Senaratna et al., 2000). From another point of view, the data indicated that the greatest accumulation of dry weight content in bulb exerted from the saline water level of 1000 ppm or the control level of $300 \mathrm{ppm}$ and the concentration of $1.0 \mathrm{mM} \mathrm{SA}$. This results may be attributed to exogenous application of SA at $1.0 \mathrm{mM}$ creates some favorable helping factors such as the increase in the photosynthetic surface, the more content of photosynthetic pigments, the improve in water status and the better stomatal conductance which may led to positive effect on accumulation of dry weight content in bulb (El Tayeb, 2005).

Regarding the water relations, the obtained results showed that the best significant value of relative water content came from foliar SA at 1.0 $\mathrm{mM}$ and the saline water level of $1000 \mathrm{ppm}$ as well as the control level of $300 \mathrm{ppm}$. This phenomenon may be attributed to the fact that foliar SA application can increase the cell turgor of leaves or epidermis thickness and lower transpiration rates (Karlidag et al., 2009).

It is concluded that spraying onion plants with SA at the concentration of $1.0 \mathrm{mM}$ reduce 
the adverse effect of saline water via improving vegetative growth, total chlorophyll, accumulation of proline and water relative content in the leaf which consequently affects bulb characteristics.

\section{REFERENCES}

Al-Safadi B. and Faoury H. (2004). Evaluation of salt tolerance in Garlic (Allium sativum L.) cultivars using in vitro techniques. Advan. Horti. Sci., 3:115-120.

Al-Zohiri S.S.M. (2009). Amelioration the adverse effect of irrigation water salinity on growth, yield and its quality of garlic plants by application of some antioxidants. The Fifth Inter. Conf. of Sustain. Agric. Develop., Fac. of Agric., Fayoum Univ.,Egypt p. 41-55.

Ali H. E. M. and Ismail G.S.M. (2014). Tomato fruit quality as influenced by salinity and nitric oxide Turk. J. Bot., 38:122-129.

Association of Official Methods of Analytical Chemists (A.O.A.C.) (1990). Official Methods of Analysis A.O.A.C. $15^{\text {th }}$ Ed. Washington, U.S.A.

Azooz M. M., Youssef A.M. and Ahmad P. (2011). Evaluation of salicylic acid (SA) application on growth, osmotic solutes and antioxidant enzyme activities on broad bean seedlings grown under diluted seawater. Int'l. J. Plant Physiol. Biochem., 14: 253264

Benbella M. (1999). Response of five sunflower genotypes (Helianthus annus L.) to different concentrations of sodium chloride. Helia., 30:125-138.

Bates S., Waldren R. and Teare I.D. (1973). Rapid determination of free proline for water-stress studies. Plant and Soil 39: 205207.

Borsani O., Valpuesta V. and Botella M.A. (2001). Evidence for a role of salicylic acid in the oxidative damage generated by $\mathrm{NaCl}$ and osmotic stress in Arabidopsis seedlings. J. Plant Physiol., 126: 1024-1030.

Change P. and Randle W. (2004). Sodium chloride in nutrient solutions can affect onion growth and flavor development. Hort. Sci., 6: 1416-1420.

El-Tayeb M.A. (2005). Response of barley grain to the interactive effect of salinity and salicylic acid. Plant Growth Regul., 42:215-224.

Flower D. J. and Ludlow M.F. (1986). Contribution of osmotic adjustment to the dehydration tolerance of water stressed pigeon pea (Cajanas cajan L.) leaves. Plant Cell Env., 9:33-40.

Gadallah M. (2000). Effects of indole-3acetic acid and zinc on the growth, osmotic potential and soluble carbon and nitrogen components of soybean plants growing under water deficit. J. Arid Environ., 44:451-467.

Hassan A.A. (1988). Onion and garlic. Al-Dar Al Arabia Lil Nashr Wa Al-Tawzeia, Cairo, Egypt, (In Arabic).

Horváth E., Pál M., Szalai G., Páldi E.and Janda T. (2007). Exogenous 4- hydroxybenzoic acid and salicylic acid modulate the effect of short-term drought and freezing stress on wheat plants. Biol. Plant., 51:480-487

Hussein M. M., El-Faham S.Y. and Alva A.K. (2012). Pepper plants growth, yield, photosynthetic pigments, and total phenols as affected by foliar application of potassium under different salinity irrigation water. Agric. Sci., 3: 241-248.

Jaleel A., Sankar B., Sridharan R., Panneersel R. (2008). Soil salinity alters growth, chlorophyll content, and secondary metabolite accumulation in Catharanthus roseus. Turk. J. Biol., (32): 79-83.

Jaleel C.A., Gopi R., Sankar B., Manivannan P., Kishorekumar A., Sridharan R. and Panneerselvam R. (2007). Studies on germination, seedling vigour, lipid peroxidation and proline metabolism in Catharanthus roseus seedlings under salt stress. South Afr. J. Bot., 73:190-195.

Javaheri M., Mashayekhi K., Dadkhah A. and Tavallaee F.Z. (2012). Effects of salicylic acid on yield and quality characters of tomato fruit (Lycopersicum esculentum Mill.). Int'l. J. Agri. Crop Sci., 4:1184-1187.

Karlidag H., Yildirim E. and Turan M. (2009). Salicylic acid ameliorates the adverse effect of salt stress on strawberry. Sci. Agric., 66:180-187

Kaydan D. and Okut M.Y. (2007). Effects of salicylic acid on the growth and some physiological characters in salt stressed wheat (Triticum aestivum L.). Tarim Bİlimleri Dergisi, (2): 114-119

Korkmaz A., Korkmaz Y. and Demirkiran A.R. (2010). Enhancing chilling stress tolerance of pepper seedling by exogenous application of 5-aminolevolinic acid. Environmental and Exper. Bot., 67: 495-501. 
Lichtenthaler H.K. (1987). Chlorophylls and Carotenoids: Pigments of Photosynthetic Biomembranes. Methods in Enzymol., 148: 350-382.

Maggio A., Reddy M.P. and Joly R.J. (2000). Leaf gas exchange and solute accumulation in the halophyte Salvadora persica grown at moderate salinity. Environ. Exp. Bot. 44: $31-38$.

Raskin I. (1992). Role of salicylic acid in plants. Ann. Rev. Plant Physiol. Plant Mol. Biol., 2: 439-463.

Sairan R. K. and Tyagi A. (2004). Physiology and molecular biology of salinity stress tolerance in plants. Curr. Sci., 86: 407-421.

Schwarz D., Klaring H.P., Iersel M. W. V. and Ingram K. T. (2002). Growth and photosynthetic response of tomato to nutrient solution concentration at two light levels. J. Amer. Soc. Hort. Sci., 127: 984990.

Senaratna T., Touchell D., Bunn T. and Dixon K. (2000). Acetyl salicylic acid (aspirin) and salicylic acid induced multiple stress tolerance in bean and tomato plants. Plant Growth Regul., 30: 157-161.

Shalhevet J. (1993). Plants under salt and water stress. In: Fowden, L., Mansfield T.,Stoddart
J. (Eds.), Plant Adaptation to Environmental Stress. Chapman and Hall, London/Glasgow/ New York/Tokyo/Melbourne/ Madras, pp. 133-154.

Simaei M., Khavari-Nejad R.A., and Bernard F. (2012). Exogenous application of salicylic acid and nitricoxide on the ionic contents and enzymatic activities in nacl-stressed soybean plants. Amer. J. Plant Sci., 3: $1495-1503$

Snedecor G.W. and Cochran W.G. (1980). Statistical Methods ( $8^{\text {th }}$ Ed.), Iowa Stat. Univ. Press. USA.

Stevens J., Senaratna T. and Silvasithamaram K. (2006). Salicylic acid induces salinity tolerance in tomato (Lycopersicon esculentum cv. Roma): associated changes in gas exchange, water relations and membrane stabilization. Pl. Growth Regul., 49:77-83.

Szepesi A., Csiszar J., Bajkan S., Gemes K., Horvath F., Erdel L., Deer A.K., Simon M.L. and Tari I. (2005). Role of salicylic acid pre-treatment on the acclimation of tomato plants to salt- and osmotic stress. Acta Biologica Szegediensis, 49: 123-125.

Zhu J.K. (2001). Plant salt tolerance. Trends Plant Sci., 6: 66-71.

$$
\begin{aligned}
& \text { تقييم تأثير حمض الساليسيليك على نمو وإنتاجية نباتات البصل تحث ظروف إجهاد الملوحة } \\
& \text { أحمد حمدي محمد عبد الواحد } \\
& \text { قسم البساتين- كلبة الزراعة - جامعة الازهر - القاهرة- مصر }
\end{aligned}
$$

\begin{tabular}{|c|}
\hline 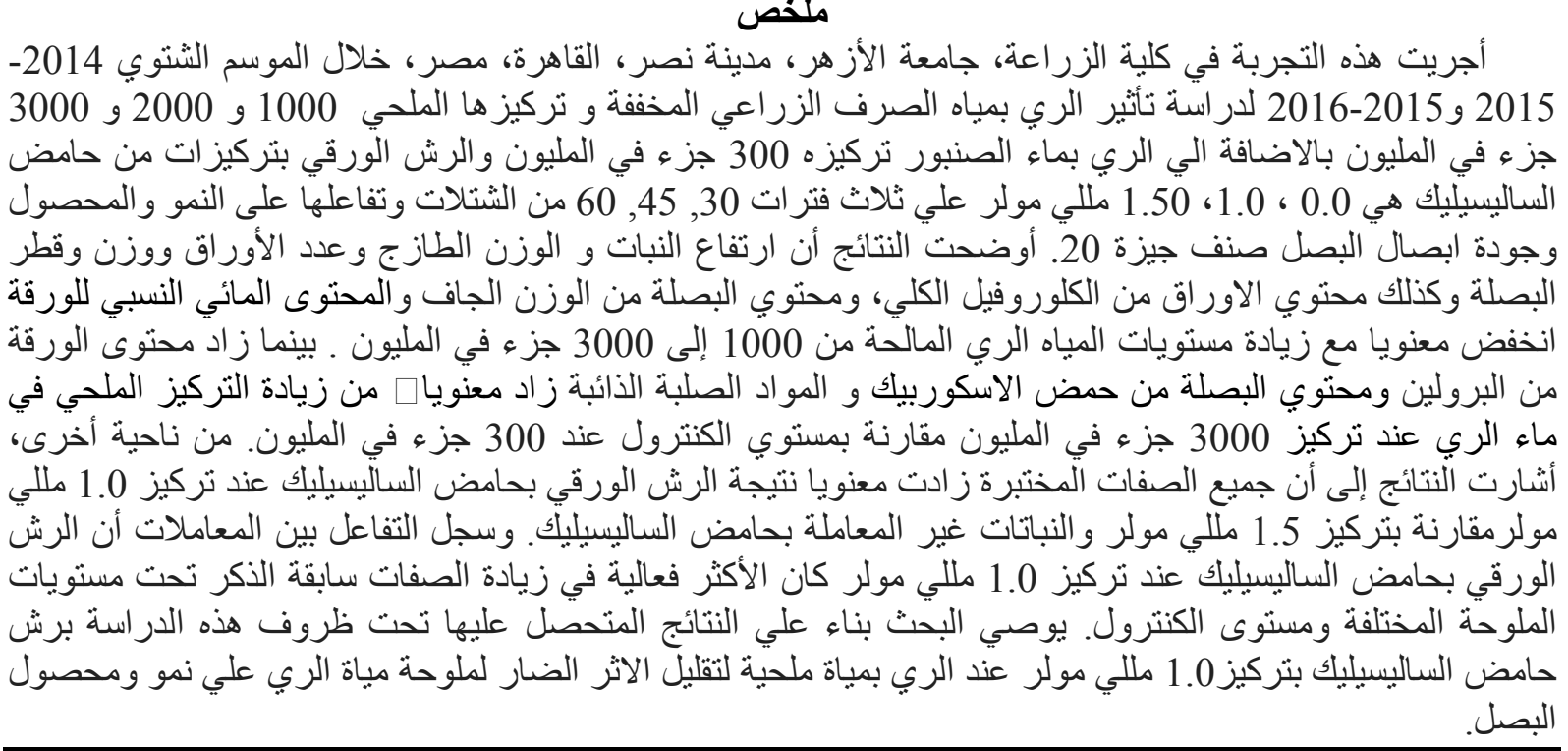 \\
\hline
\end{tabular}

